\title{
Comparison of growth, behavior and lipid concentrations of walleye pollock Theragra chalcogramma larvae fed lipid-enriched, lipid-deficient and field-collected prey
}

\author{
Michael W. Davis, Bori L. Olla \\ Cooperative Institute for Marine Resource Studies, Alaska Fisheries Science Center, National Marine Fisheries Service, \\ Hatfield Marine Science Center, Newport, Oregon 97365, USA
}

\begin{abstract}
While growth and survival of marine fish larvae in the sea may be dependent on prey type, size and concentration, nutritional quality of prey may also play an important role. This study investigates the relationships of lipid content of prey with growth, gas bladder size, sinking rate, behavior and survival for larval walleye pollock Theragra chalcogramma under controlled conditions in the laboratory. Larvae fed lipid-deficient brine shrimp Artemia spp. nauplii had reduced growth, gas bladder size and survival. These larvae also had to swim almost continuously to maintain vertical position in the water column. In contrast, larvae fed wild-caught copepods or Artemia spp. enriched with lipid showed alternating swimming and resting bouts. The potential for vagaries in meteorological and oceanographic conditions to cause larval fish prey to be nutrient deficient is discussed.
\end{abstract}

\section{INTRODUCTION}

Starvation has been generally recognized as one of the major causes of mortality for marine fish larvae (Hunter 1981). Availability, abundance, type and size of prey have all been shown to be critical for successful larval feeding (Lasker 1975, 1981). More recently, studies have suggested that nutritional quality of prey in the sea may affect larval growth and survival (Hakanson 1989, Klungsøyr et al. 1989). Our intent in this study was to examine the role that nutritional quality of prey plays in the growth, behavior and survival of walleye pollock Theragra chalcogramma larvae under controlled laboratory conditions. This species is widely distributed in the North Pacific Ocean and Bering Sea and is one of the most intensively exploited finfish in the world (FAO 1988).

Both prey type and density can limit growth and survival for Theragra chalcogramma larvae in the laboratory and the sea (Bailey \& Stehr 1986, Kendall et al. 1987). In the Gulf of Alaska, copepod nauplii have been identified as the primary food source for $T$. chalcogramma larvae 5 to $12 \mathrm{~mm}$ in length (Kendall et al. 1987, Grover 1990).
Mixing in the sea, associated with physical factors, e.g. wind, currents and upwelling, can create spatial and temporal variation of primary production (Mullin $\&$ Brooks 1976, Haury et al. 1978). This variation may create discontinuous feeding patterns for copepods, which can lead to a depletion of lipid or amino acid energy stores and eventual death (Dagg 1977, Borchers \& Hutchings 1986, Willason et al. 1986, Attwood \& Peterson 1989, Rajendran et al. 1991).

The role of lipid composition of prey in the growth and survival of marine fish larvae has been widely studied in the laboratory. Cultivation of various species of marine fish larvae has shown that highly unsaturated fatty acids (HUFA), especially eicosapentaenoic acid (EPA, $20: 5 n-3)$ and docosahexaenoic acid (DHA, 22:6n-3), are essential components of membrane phospholipids necessary for survival (Watanabe 1982, Watanabe et al. 1983, Bell et al. 1986). Copepod nauplii are rich sources for HUFA (Lee et al. 1971, Fraser et al. 1989). In contrast, live prey such as the rotifer Brachionus plicatilis and brine shrimp (Artemia salina) nauplii used in cultivation of marine fish larvae are often deficient in HUFA and need to be artificially enriched to sustain fish growth 
and survival (Watanabe et al. 1983). In addition, free amino acids have been shown to be important as energy substrates for early stage marine fish larvae (Dabrowski \& Rusiecki 1983, Dendrinos \& Thorpe 1987 , Fyhn \& Serigstad 1987, Fyhn 1989).

Larval fish behavior may be modified by physical changes associated with deficient lipid composition. For example, total lipid concentration for marine fish larvae can directly control changes in buoyancy (Blaxter \& Ehrlich 1974). Lipid deficiency of prey has been shown to be associated with dysfunction of the gas bladder for red sea bream Pagrus major (Kitajima et al. 1981) and sea bass Dicentrarchus labrax (Katavic 1986). Inhibition of proper gas bladder function can result in the loss of hydrostatic regulation (Blaxter \& Tytler 1978, Katavic 1986) which may be important for reducing the energetic cost of swimming and improving predatory efficiency (Alexander 1972, Hunter 1972). Improper development and functioning of the gas bladder and associated glandular epithelium and rete mirabile is a common problem for cultured marine fish larvae that is accompanied by loss of hydrostatic regulation and eventual death (Schwarz 1971, Doroshev et al. 1981, Battaglene \& Talbot 1990).

Results of an initial experiment showed that increased growth, gas bladder development and survival of larval Theragra chalcogramma was associated with slight lipid enrichment of Brachionus plicatilis and Artemia salina nauplii prey. To substantiate these findings, we designed a second experiment using prey with widely differing lipid concentrations, i.e. Artemia franciscana nauplii and wild-caught Acartia spp. copepod nauplii and copepodites.

\section{METHODS}

Adult Theragra chalcogramma were collected by hook and line from Tacoma Narrows, Washington, USA $\left(47^{\circ} \mathrm{N}, 123^{\circ} \mathrm{W}\right)$ or reared to adulthood in the laboratory from juveniles collected from Pt. Townsend Harbor, Washington $\left(48^{\circ} \mathrm{N}, 123^{\circ} \mathrm{W}\right)$. Naturally spawned eggs were reared at 6 or $9^{\circ} \mathrm{C}$ in the laboratory under conditions described by Olla \& Davis (1990). Aquaria $(25 \times 50 \times 30 \mathrm{~cm}, 20$ l) were each stocked with 500 larvae (25 ind. $1^{-1}$ ).

The first experiment was a preliminary growth trial conducted at $9^{\circ} \mathrm{C}$ with eggs spawned from fieldcollected adults. Brachionus plicatilis was used as live prey for the first $18 \mathrm{~d}$ of growth. From Days 14 to 45 , freshly hatched Artemia salina (Phoenix Brand, Western Brine Shrimp Co.), were used as live prey. B. plicatilis was reared on the alga Isochrysis galbana (SERI strain ISOCH01) and baker's yeast (Fleischmann's; $0.02 \mathrm{~g} \mathrm{I}^{-1}$ ). A. salina nauplii were hatched and held in seawater for $24 \mathrm{~h}$ before feeding. Aquaria were stocked daily to maintain $B$. plicatilis at 20 ind. $\mathrm{ml}^{-1}$ or A. salina ( $24 \mathrm{~h}$ old) at 1 to 2 ind. $\mathrm{ml}^{-1}$, as determined with counts of 4 replicate $1 \mathrm{ml}$ samples from each aquarium.

Food treatments in the first experiment consisted of single aquaria each containing 500 Theragra chalcogramma larvae and supplied with either lipid-deficient and lipid-enriched prey. Brachionus plicatilis and Artemia salina prey for the lipid-deficient aquarium were grown on lipid-rich algae (Isochrysis galbana), but were not enriched with a lipid emulsion before feeding. B. plicatilis and A. salina for the lipid-enriched aquarium were grown on I. galbana and were enriched with an emulsion containing HUFA, made from crude Atlantic menhaden Brevoortia tyrannus fish oil (Zapata Haynie Corp., Lot \#0899, Tank \#8), egg yolkphosphatidylcholine (Sigma Chemical), and seawater $(5: 2: 95 \mathrm{v}: \mathrm{w}: \mathrm{v})$ mixed with baker's yeast (Fleischmann's) and seawater $(0.1: 0.25: 1000 \mathrm{v}: \mathrm{w}: \mathrm{v})$. B. plicatilis and $A$. salina were incubated in the enrichment solution $24 \mathrm{~h}$ before feeding to $T$. chalcogramma larvae in the lipid-enriched aquarium. Feeding activity by $B$. plicatilis and $A$. salina resulted in uptake of the emulsion-yeast mixture as verified by Congo Red staining of the mixture and visual inspection of the prey. B. plicatilis and A. salina for the lipid-deficient aquarium were incubated for $24 \mathrm{~h}$ in baker's yeast and seawater $(0.25: 1000 \mathrm{w}: \mathrm{v})$.

Length $( \pm 0.01 \mathrm{~mm})$, gas bladder size $\left( \pm 0.01 \mathrm{~mm}^{2}\right)$ and sinking rate $\left( \pm 0.01 \mathrm{~cm} \mathrm{~s}^{-1}\right)$ of 20 Theragra chalcogramma larvae from each food treatment were measured at 14,21, 28 and $34 \mathrm{~d}$ after hatching. Gut fullness was also assessed to determine whether larvae had fed. The maximum length and width of a gas bladder ( $\pm 0.01 \mathrm{~mm}$ ) was measured and multiplied together to express maximum gas bladder cross-sectional area, a relative measure of gas bladder size. Sinking rate was measured as the time for freshly killed larvae (dipped in $4 \%$ buffered seawater formalin and immediately rinsed in $32 \mathrm{ppt}$ seawater) to sink $10 \mathrm{~cm}$ in seawater (32 ppt salinity, $9^{\circ} \mathrm{C}$ ) expressed as $\mathrm{cm} \mathrm{s}^{-1}$. This treatment did not alter the size of larvae or the gas bladder prior to measurements, which were made within $15 \mathrm{~min}$ of sampling. Observations also were made of larval swimming, resting and sinking behavior, expressed as percent total larvae observed ( $n=50$ ind. aquaria ${ }^{-1}$ ).

In the second experiment naturally spawned eggs were obtained from adult Theragra chalcogramma that were reared in the laboratory. Eggs were hatched and larvae were incubated at $6^{\circ} \mathrm{C}$ in 3 replicate aquaria for each of 2 treatments representing lipid-enriched and lipid-deficient prey. Larvae in both treatments were fed Brachionus plicatilis for the first $18 \mathrm{~d}$ of growth. $B$. plicatilis was reared as described above except that 
prey were soaked $24 \mathrm{~h}$ before feeding in either seawater (lipid-deficient prey) or in seawater with a commercial lipid supplement (lipid-enriched prey) at $0.2 \mathrm{~g} \mathrm{l}^{-1}$ (Microfeast L-10; Provesta Corp.). Beginning $14 \mathrm{~d}$ after hatching and continuing until termination of the experiment, larger prey were introduced. The 3 aquaria that had been given the lipid-enriched $B$. plicatilis received wild zooplankton collected daily from the same site in the Yaquina Estuary, Oregon, USA $\left(45^{\circ} \mathrm{N}, 124^{\circ} \mathrm{W}\right)$, and filtered through nylon mesh (200 to $550 \mu \mathrm{m}$ ). These plankton consisted almost entirely of Acartia clausi and A. tonsa nauplii and copepodite stages. The 3 other aquaria that had been given lipid-deficient $B$. plicatilis received freshly hatched Artemia franciscana (Platinum grade, Argent Chemicals). Prey were stocked at concentrations used in the first experiment.

Twenty larvae were sampled from each replicate aquaria 14, 16, 22, 28 and $36 \mathrm{~d}$ after hatching. Gut fullness, length, gas bladder size, sinking rates and swimming and sinking behavior were determined as described above. For lipid analysis, 50 larvae were sampled and pooled from each replicate aquarium $22 \mathrm{~d}$ after hatching. Samples of Brachionus plicatilis and Artemia franciscana were also taken at that time from prey cultures, while samples of wild-caught Acartia spp. were taken from field collections fed to larvae $16 \mathrm{~d}$ (10 May 1991) and 28 d (22 May 1991) after hatching. In this experiment formalin-killed or anesthetized Theragra chalcogramma larvae almost always sank, even in high salinity water (45 ppt). Attempts were made to measure sinking rates of larvae treated with various anesthetics including phenoxyethanol (50 ppm, Sigma Chemical), ethyl p-aminobenzoate (50 ppm, Sigma Chemical), and 3-aminobenzoic acid ethyl ester methane sulfonate ( $75 \mathrm{ppm}$, Sigma Chemical). In all cases of anesthetic use, deformation of larvae was noted and no differences in sinking rates were noted for larvae between chemicals tested. Reduced concentrations of anesthetics did not change our results. Apparently, once larvae had been immobilized, they lost buoyancy.

For the first experiment, fatty acids of fish oil emulsion, Isochrysis, lipid-enriched and lipid-deficient Brachionus plicatilis and Artemia salina were extracted in hexane:isopropanol $(3: 2 \mathrm{v}: \mathrm{v})$ after the method of Radin (1981) and analyzed using a HP 5890 gas chromatograph and SP-2330 (cyanosilicon) capillary column (Supelco; $0.2 \mu \mathrm{m}$ film, $0.25 \mathrm{~mm} \mathrm{ID} \times 30 \mathrm{~m}$ length). Split ratio was $68: 1$, injector and detector temperatures were $220^{\circ} \mathrm{C}$. Temperature program was $175^{\circ} \mathrm{C}$ for $8 \mathrm{~min}$ then to $210^{\circ} \mathrm{C}$ at a $5^{\circ} \mathrm{C} \mathrm{min}$ m $^{-1}$ ramp using $\mathrm{He}$ carrier gas at $0.86 \mathrm{ml} \mathrm{min}^{-1}$ with $\mathrm{N}_{2}$ makeup gas. Fatty acid peaks from samples were identified by comparing their retention times with those of known standards. Lipid standards used were PUFA 1 (marine source) and PUFA 2 (animal source) from Supelco and assorted purified fatty acids from Supelco, Sigma and Nu Chek Prep. For the second experiment, lipids were extracted from samples following the method of Bligh \& Dyer (1959) using methanol and chloroform. For each sample, total lipids were measured gravimetrically from an aliquot of this extraction. A second aliquot of the lipid extract was used to determine the fatty acid profile according to previously reported procedures (Song \& Wander 1991). Moisture of the samples was determined gravimetrically.

In the second experiment, 2 -way analysis of variance was performed with mean values from replicate aquaria ( $n=3$ ) for Theragra chalcogramma length, gas bladder size and sinking rate. Variances for the raw data were not equal (Hartley test) and data were transformed to ranks prior to analysis of variance. One-way analysis of variance was performed with mean values from replicate aquaria $(n=3$ ) for lipid concentrations and percent moisture of $T$. chalcogramma larvae and their prey (Brachionus plicatilis, Acartia spp. and Artemia franciscana). Differences between means were determined by Scheffe comparisons at $p=0.05$

\section{RESULTS}

In the first experiment, average length and gas bladder size of Theragra chalcogramma larvae fed a lipid-enriched diet was greater than for those fed a lipid-deficient diet (Fig. 1). While larvae under both treatments had inflated gas bladders by first feeding

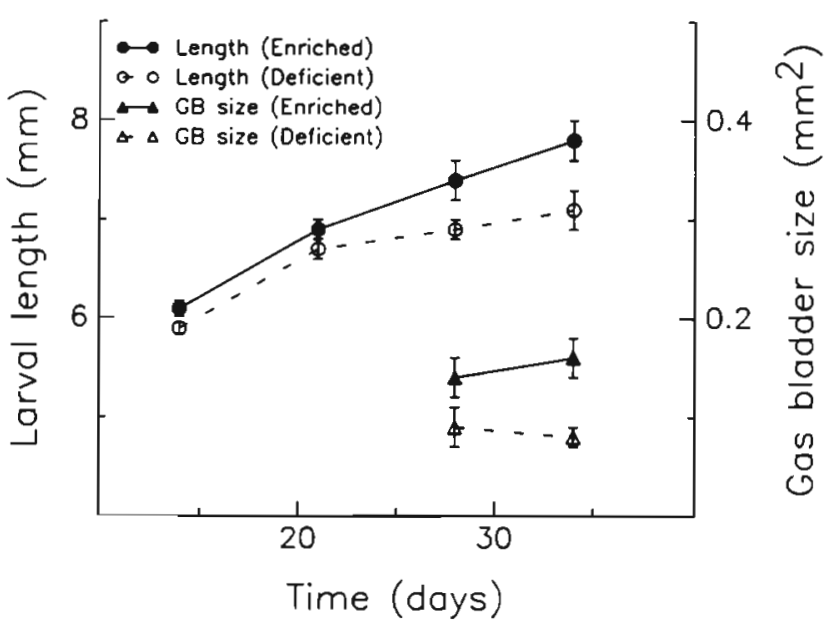

Fig. 1. Theragra chalcogramma. Expt 1. Walleye pollock lar$\mathrm{val}$ increase in length $(\mathrm{mm})$ and gas bladder (GB) size $\left(\mathrm{mm}^{2}\right)$ during the first $34 \mathrm{~d}$ of growth at $9^{\circ} \mathrm{C}$. Values are mean $\pm \mathrm{SE}$ for 20 larvae from single replicate aquaria fed with either lipid-enriched ('Enriched') or lipid-deficient ('Deficient') Artemia salina 
readiness $\left(99 \%, 4 \mathrm{~d}\right.$ after hatching at $\left.9^{\circ} \mathrm{C}\right)$, those fed a lipid-deficient diet did not show a subsequent increase in gas bladder size. Mortality also differed with larvae fed a lipid-enriched diet surviving $45 \mathrm{~d}$ and those fed a lipid-deficient diet $34 \mathrm{~d}$ at $9{ }^{\circ} \mathrm{C}$. Observed differences could be attributed to lipid content of prey since all larvae sampled had food in their guts.

Observations of swimming behavior for larvae ( $\mathrm{n}=$ 20 in each treatment) were made 28 and $34 \mathrm{~d}$ after hatching. For larvae fed a lipid-enriched diet, swimming under simulated daylight was generally horizontal alternating with rest periods during which $94 \pm$ $3 \%$ (mean $\pm \mathrm{SE}$ ) of larvae sank slowly, with a horizontal orientation as described in an earlier study (Olla \& Davis 1990). For larvae that had been fed a lipiddeficient diet, while swimming, the orientation was horizontal, but with almost no rest periods. When they did rest, $8 \pm 4 \%$ of larvae sank in the normal horizontal orientation, while $92 \pm 4 \%$ of larvae were oriented near the vertical, sinking head first. Sinking rate of fresh killed larvae $(n=20$ in each treatment, mean $\pm \mathrm{SE}$ ) was slower for larvae fed a lipid-enriched diet $\left(0.18 \pm 0.12 \mathrm{~cm} \mathrm{~s}^{-1}\right)$ than for larvae fed a lipid-deficient diet $\left(0.29 \pm 0.12 \mathrm{~cm} \mathrm{~s}^{-1}\right)$.

Enrichment with fatty acids increased slightly the percent of eicosapentaenoic acid (EPA, 20:5n-3) and docosahexaenoic acid (DHA, 22:6n-3) for Brachionus plicatilis, while only the percent of EPA was increased for Artemia salina (Table 1). A. salina did not contain DHA initially and apparently were not able to assimilate this HUFA. Although enrichment of $A$. salina with the lipid supplement appeared to be slight, nonetheless, the observed differences in growth and behavior of larvae indicated that enrichment had occurred. This suggested that greater differences in growth and behavior could be observed by performing an experiment using prey of widely differing lipid concentrations, i.e. A. franciscana and the copepod Acartia spp.

In the second experiment, mean length $16 \mathrm{~d}$ after hatching was greater for larvae fed lipid-enriched Brachionus plicatilis than for larvae fed lipid-deficient $B$. plicatilis (Fig. 2; $t$-test, $\mathrm{df}=4, t=10.9, \mathrm{p}<0.001$ ) while gas bladder size did not differ (Fig. $3 ; t=1.48, p=0.212$ ). Through the rest of the experiment, larvae fed wildcaught Acartia spp. had greater mean length and gas bladder size than larvae fed lipid-deficient Artemia franciscana nauplii (Figs. 2 \& 3) (length, $F_{1.16}=41.68$, $\mathrm{p}<0.001$; gas bladder size, $\left.F_{1,16}=61.07, \mathrm{p}<0.001\right)$. As in the first experiment, larvae $(99 \%$ ) had inflated gas bladders by first feeding readiness (5 $\mathrm{d}$ after hatching at $6^{\circ} \mathrm{C}$ ), but larvae fed lipid-deficient prey showed little increase in gas bladder size through time. Feeding was

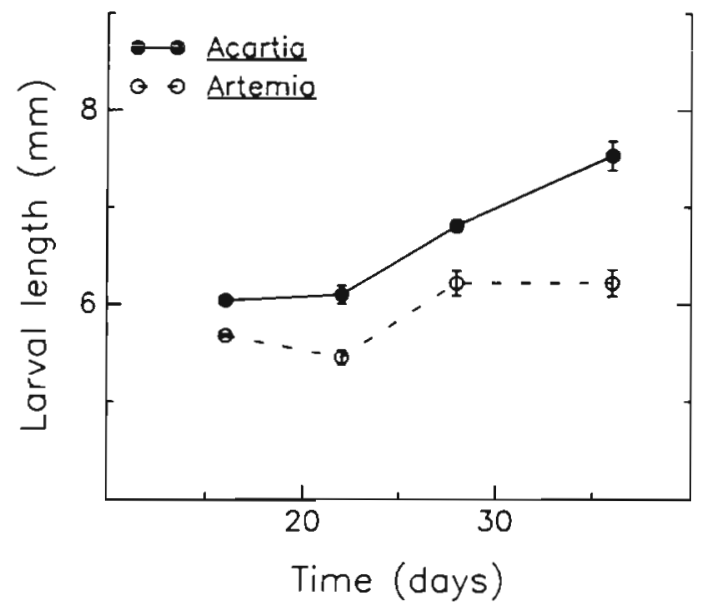

Fig. 2. Theragra chalcogramma. Expt 2. Walleye pollock larval increase in length (mm) during the first $36 \mathrm{~d}$ of growth at $6^{\circ} \mathrm{C}$. Values are mean $\pm \mathrm{SE}$ for 3 replicate aquaria fed with either Artemia franciscana or wild-caught Acartia spp.

Table 1. Fatty acids (\% total fatty acid content) in food of walleye pollock larvae for Expt 1. Values are mean of duplicate samples from lipid enrichment emulsion (Brevoortia tyrannus oil emulsion), algal (Isochrysis galbana) cultures or prey cultures (Brachionus plicatilis or Artemia salina) which had been enriched with ('Enriched') or were deficient in ('Deficient') lipids

\begin{tabular}{|c|c|c|c|c|c|c|}
\hline \multirow[t]{2}{*}{ Fatty acid } & \multirow{2}{*}{$\begin{array}{c}\text { Brevoortia tyrannus } \\
\text { oil emulsion }\end{array}$} & \multirow{2}{*}{$\begin{array}{l}\text { Isochrysis } \\
\text { galbana }\end{array}$} & \multicolumn{2}{|c|}{ Brachionus plicatilis } & \multicolumn{2}{|c|}{ Artemia salina } \\
\hline & & & Deficient & Enriched & Deficient & Enriched \\
\hline $14: 0$ & 9.3 & 8.7 & 3.5 & 4.2 & 1.5 & 1.6 \\
\hline $16: 0$ & 24.0 & 7.3 & 9.5 & 10.2 & 14.1 & 14.5 \\
\hline $16: 1 n-7$ & 9.2 & 5.0 & 24.2 & 23.9 & 12.8 & 12.5 \\
\hline $18: 0$ & 7.1 & 0.9 & 3.9 & 3.6 & 4.0 & 4.1 \\
\hline $18: 1 n-7$ & 3.1 & 5.0 & 4.7 & 4.1 & 17.0 & 16.1 \\
\hline $18: 1 n-9$ & 12.4 & 9.9 & 19.0 & 18.1 & 17.7 & 17.7 \\
\hline $18: 2 n-6$ & 5.7 & 16.1 & 8.0 & 7.8 & 12.1 & 12.3 \\
\hline $18: 3 n-3$ & 0.6 & 7.6 & 3.0 & 2.9 & 0.8 & 0.5 \\
\hline $18: 4 n-3$ & 2.6 & 15.3 & 1.9 & 2.3 & 0.2 & 0.2 \\
\hline $20: 5 n-3$ & 9.1 & 4.9 & 2.3 & 3.5 & 5.0 & 5.5 \\
\hline $22: 5 n-3$ & 1.1 & 0.0 & 0.0 & 0.6 & 0.0 & 0.0 \\
\hline $22: 6 n-3$ & 5.5 & 12.6 & 2.2 & 2.9 & 0.0 & 0.0 \\
\hline
\end{tabular}




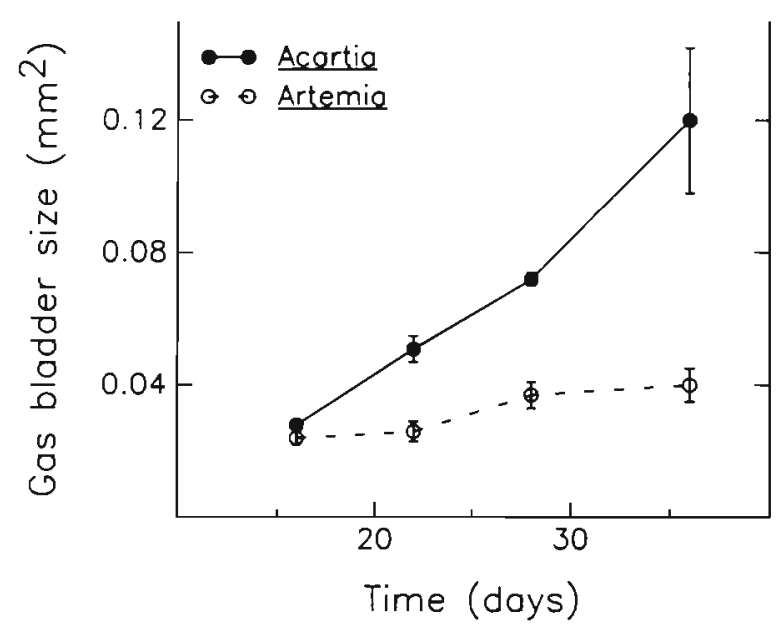

Fig. 3. Theragra chalcogramma. Expt 2. Walleye pollock larval increase in gas bladder size $\left(\mathrm{mm}^{2}\right)$ during the first $36 \mathrm{~d}$ of growth at $6^{\circ} \mathrm{C}$. Values are mean $\pm \mathrm{SE}$ for 3 replicate aquaria fed with either Artemia franciscana or wild-caught Acartia spp.

apparent for all larvae sampled and guts were full regardless of feeding on A. franciscana or Acartia spp.

Larvae showed the same characteristic swimming patterns described for the first experiment. Larvae fed wild-caught Acartia spp. exhibited normal horizontal swimming interspaced with rest periods in which $92 \pm$ $2 \%$ (mean \pm SE) of larvae sank slowly in a horizontal orientation. Larvae fed lipid-deficient Artemia franciscana exhibited nearly continuous swimming interspaced with rare resting periods in which $4 \pm 3 \%$ of larvae sank in a normal horizontal orientation and $96 \pm 3 \%$ of larvae sank head down. Although sinking rate varied over time for all larvae, food type did not cause differences in sinking rate between treatments $\left(F_{1,16}=3.21, \mathrm{p}=0.092\right)$. Larvae fed lipid-deficient A. franciscana did not survive past $42 \mathrm{~d}$ at $6{ }^{\circ} \mathrm{C}$, while approximately $40 \%$ of larvae fed wild-caught Acartia spp. survived at $42 \mathrm{~d}$ and $2 \%$ survived through metamorphosis ( $80 \mathrm{~d}$ after hatching).
Total lipid, EPA and DHA (mg g ${ }^{-1}$ dry wt) were 2.7 , 5.3 and 7.1 times more abundant for larvae fed wildcaught Acartia spp. than for larvae fed lipid-deficient Artemia franciscand, although these differences were not significant (Table 2) primarily because of the high variance for the larvae fed wild Acartia spp. Fatty acid content (\% total fatty acid content) of Theragra chalcogramma generally matched that of their prey (Table 3 ). Larvae fed wild Acartia spp. had a higher percentage of 20:5n-3 and 22:6n-3, while larvae fed $A$. franciscana had a higher percentage of $18: 1 \mathrm{n}-9,18: 2 \mathrm{n}-6$ and $18: 3 n-3$.

Although Artemia franciscana had the highest total lipid, they had low levels of EPA and no DHA (Table 2), as was found for $A$. salina used in Expt 1 (Table 1).

Lipid concentrations for wild-caught Acartia spp. were variable through time. Those collected on 22 May had 5.1 times more total lipid, 5.3 times more EPA and 25.8 times more DHA than wild Acartia spp. collected on 10 May at the same site.

\section{DISCUSSION}

The results of our experiments showed that Brachionus plicatilis was suitable prey for the early growth of Theragra chalcogramma larvae, while wild-caught Acartia spp. was suitable for continued growth and eventual metamorphosis. Artemia spp. however, was not adequate food. The growth rate of larval $T$. chalcogramma fed wild copepods was $0.21 \mathrm{~mm} \mathrm{~d}^{-1}$ with this falling within the range of 0.12 to $0.25 \mathrm{~mm} \mathrm{~d}^{-1}$ found for larvae in the Gulf of Alaska (Kendall et al. 1987, Yoklavich \& Bailey 1990) and for larvae reared in the laboratory on mixed wild zooplankton and yeastenriched B. plicatilis (Bailey \& Stehr 1986). When fed lipid-deficient Artemia spp. nauplii in the present study, larval growth was only 0.03 to $0.04 \mathrm{~mm} \mathrm{~d}^{-1}$ reflecting the nutrient deficiency of this type of prey. Previous research has also shown Artemia spp. to be deficient prey for many species of marine fish larvae

Table 2. Lipid concentration ( $\mathrm{mg} \mathrm{g}^{-1} \mathrm{dry} w \mathrm{w}$ ) and \% moisture of walleye pollock larvae (22 $\mathrm{d}$ after hatching) and their food for Expt 2. Values are mean $( \pm S D$ ) of 3 replicate samples from aquaria that were stocked with wild Acartia spp. and aquaria stocked with Artemia franciscana. Values are given for lipid-enriched Brachionus plicatilis initially fed to fish larvae. No significant differences ( $t$-test, $p>0.05$ ) were apparent between larvae fed Acartia spp. and A. franciscana. Mean values for larval prey within a column sharing a letter are not significantly different (1-way ANOVA, $p>0.05$ )

\begin{tabular}{|c|c|c|c|c|c|c|c|c|}
\hline \multirow[b]{2}{*}{ Larvae fed Acartia spp. } & \multicolumn{2}{|c|}{ Total lipid } & \multicolumn{2}{|c|}{$20: 5 n-3$} & \multicolumn{2}{|c|}{$22: 6 n-3$} & \multicolumn{2}{|c|}{$\%$ Moisture } \\
\hline & 176.7 & (129.9) & 20.6 & $(17.6)$ & 59.2 & $(49.7)$ & 94.1 & $(1.3)$ \\
\hline Larvae fed Artemia franciscana & 65.4 & $(23.0)$ & 3.9 & $(1.8)$ & 8.3 & $(4.2)$ & 94.0 & $(0.3)$ \\
\hline Acartia spp. (10 May 91) & 18.8 & $(10.0)^{c}$ & 2.7 & $(1.6)^{\mathrm{b}}$ & 0.8 & $(0.3)^{b}$ & 95.1 & $(0.6)^{\circ}$ \\
\hline Acartia spp. (22 May 91) & 96.6 & $(16.0)^{b}$ & 14.2 & $(2.4)^{\mathrm{a}}$ & 20.1 & $(2.2)^{\mathrm{d}}$ & 90.4 & $(1.0)^{\circ}$ \\
\hline Artemia franciscana & 171.1 & $(21.9)^{d}$ & 2.8 & $(0.3)^{\mathrm{b}}$ & 0.0 & $(0.0)^{b}$ & 88.1 & $(1.3)^{\mathrm{c}}$ \\
\hline Brachionus plicatilis & 63.0 & $(24.9)^{b}$ & 1.6 & $(0.7)^{\mathrm{b}}$ & 3.1 & $(1.4)^{\mathrm{b}}$ & 87.9 & $(5.2)^{\mathrm{c}}$ \\
\hline
\end{tabular}


Table 3. Fatty acids (\% total fatty acid content) in walleye pollock larvae ( $22 \mathrm{~d}$ after hatching) and their food for Expt 2 . Values are mean $( \pm$ SD) of 3 replicate samples from aquaria that were stocked with wild Acartia spp. and aquaria stocked with Artemia franciscana. Values are given for lipid-enriched Brachionus plicatilis initially fed to fish larvae

\begin{tabular}{|c|c|c|c|c|c|c|}
\hline \multirow{2}{*}{$\begin{array}{l}\text { Fatty } \\
\text { acid }\end{array}$} & \multirow{2}{*}{$\begin{array}{l}\text { Larvae fed } \\
\text { Acartia spp. }\end{array}$} & \multirow{2}{*}{$\begin{array}{c}\text { Larvae fed } \\
\text { Artemia franciscana }\end{array}$} & \multicolumn{2}{|c|}{ Acartia spp. } & \multirow{2}{*}{$\begin{array}{c}\text { Artemia } \\
\text { franciscana }\end{array}$} & \multirow{2}{*}{$\begin{array}{l}\text { Brachionus } \\
\text { plicatilis }\end{array}$} \\
\hline & & & (10 May 91 ) & (22 May 91) & & \\
\hline $14: 0$ & $1.0(0.2)$ & $0.9(0.1)$ & $6.6(1.4)$ & $2.2(0.7)$ & $0.9(0.1)$ & $7.7(0.7)$ \\
\hline $16: 0$ & $17.6(0.4)$ & $13.6(1.0)$ & $12.1(1.7)$ & $20.4(1.6)$ & $14.4(0.2)$ & $9.6(0.3)$ \\
\hline $16: 1 n-7$ & $1.2(0.3)$ & $3.8(0.4)$ & $8.7(0.7)$ & $1.1 \quad(0.2)$ & $9.8(0.2)$ & $6.4(0.1)$ \\
\hline $18: 0$ & $7.0 \quad(0.6)$ & $6.1(0.3)$ & $4.7 \quad(2.9)$ & $3.6(0.8)$ & $3.4(0.0)$ & $3.4(0.1)$ \\
\hline $18: 1 n-7$ & $3.0(0.2)$ & $5.1 \quad(0.6)$ & $1.2(0.2)$ & $2.3(0.0)$ & $8.1(0.1)$ & $3.6(0.1)$ \\
\hline $18: 1 n-9$ & $5.1(0.3)$ & $11.4(0.9)$ & $5.1(2.7)$ & $2.3(0.2)$ & $21.8(0.1)$ & $10.4(0.3)$ \\
\hline $18: 2 n-6$ & $1.1(0.1)$ & $4.2(0.4)$ & $1.7(0.2)$ & $2.5(0.1)$ & $6.6(0.0)$ & $13.5(0.4)$ \\
\hline $18: 3 n-3$ & $0.9(0.1)$ & $6.8(0.7)$ & $0.7(0.1)$ & $6.4 \quad(0.5)$ & $20.1 \quad(0.2)$ & $5.6(0.2)$ \\
\hline $18: 4 n-3$ & $0.7(0.3)$ & $1.3(0.1)$ & $1.6(0.2)$ & $10.7(1.8)$ & $3.8(0.0)$ & $4.3(0.1)$ \\
\hline $20: 5 n-3$ & $10.2(2.7)$ & $5.8(0.7)$ & $14.0(4.7)$ & $14.7(0.2)$ & $1.7(0.0)$ & $2.4(0.1)$ \\
\hline $22: 5 n-3$ & $1.1 \quad(0.2)$ & $0.8(0.1)$ & $0.3(0.2)$ & $1.1(0.1)$ & $0.0 \quad(0.0)$ & $0.2(0.1)$ \\
\hline $22: 6 n-3$ & $30.1(6.1)$ & $12.4\{1.9\}$ & $4.3(1.1)$ & $21.0(1.0)$ & $0.0(0.0)$ & $4.8 \quad(0.1)$ \\
\hline
\end{tabular}

(Watanabe 1982, Watanabe et al. 1983, Leyer ei al. 1986. Webster \& Lovell 1990, Tuncer \& Harrell 1992). Possible nutritional factors responsible for reduced growth and increased mortality of laboratory-reared $T$. chalcogramma larvae fed Artemia spp. nauplii include reduced concentrations of highly unsaturated fatty acids (HUFA) (Watanabe 1982, Watanabe et al. 1983), free amino acids (Fyhn 1989) and digestive enzymes (Pedersen \& Hjelmeland 1988)

Several factors lead us to hypothesize that Theragra chalcogramma larvae could encounter nutrient-deficient prey in the sea. Essential HUFA are synthesized de novo only by photosynthetic organisms, making them essential dietary factors for copepods and larval fish (Bell et al. 1986, Fraser et al. 1989). It is evident that upwelling, vertical and horizontal sheers, diffusion, turbulence, advection, or frequency of storms can contribute to mixing in the sea, in turn leading to temporal and spatial variation in distributions of phytoplankton and copepods (Mullin \& Brooks 1976, Haury et al. 1978, Willason et al. 1986, Attwood \& Peterson 1989). Such variation creates discontinuous feeding patterns for copepods and disruption of HUFA transfer within food webs (Rajendran et al. 1991). Analysis of lipids in copepodite and adult stages of the copepods Calanus pacificus and $C$. australis shows that even short periods of food deprivation ( 1 to $6 \mathrm{~d}$ ) caused by variation of phytoplankton distribution causes both triglyceride and wax ester fractions to decrease markedly (Hakanson 1984, Attwood \& Peterson 1989); or cause death in 6 to $10 \mathrm{~d}$ for adult Acartia tonsa, which does not store large amounts of wax esters (Dagg 1977), or naupliar, copepodite and adult stages of Calanoides carinatus, which store lipid in a droplet (Borchers \& Hutchings 1986). In the present study, we found a 10 -fold increase in HUFA content of wild Acartia spp. from a single site over a period of $2 \mathrm{wk}$, further supporting the hypothesis that distribution of HUFA in nature can be variable and may lead to fluctuating supply of essential fatty acids for fish larvae.

HUFA can be supplied directly or indirectly to fish larvae from various sources including Isochrysis galbana, Brachionus plicatilis and Artemia spp (Watanabe et al. 1983, Opstad et al. 1989, Napolitano et al. 1990). Studies of the HUFA content of cod Gadus morhua have shown that both $20: 5 n-3$ and $22: 6 n-3$ are abundant in eggs and larvae, as well as nauplii of Calanus finmarchicus, an important food item for G. morhua larvae (Fraser et al. 1988, Klungsoyr et al. 1989). In our study, 20:5n-3 and 22:6n-3 were abundant in Theragra chalcogramma larvae and were provided to the larvae from $B$. plicatilis and wild Acartia spp. However, 22:6n-3 was not present in Artemia spp. nauplii nor did they assimilate it when exposed to HUFA via I. galbana or a lipid-enrichment emulsion. Similarly, a lack of $22: 6 n-3$ has been observed for Artemia spp. in other studies, even upon lipid enrichment (Leger et al. 1986, Webster \& Lovell 1990, Lemm \& Lemarie 1991, Tuncer \& Harrell 1992). Therefore, $T$. chalcogramma larvae did not receive $22: 6 n-3$ when Artemia spp. was fed after $14 \mathrm{~d}$, but instead relied upon internal stores supplied from B. plicatilis for metabolism and growth. These lipid stores were probably depleted over time, resulting in decreased growth and survival. Depletion of lipid stores was observed for striped bass Morone saxatilis when fed Artemia spp. and it was suggested that marine fish larvae generally do not have the ability to form 22:6n-3 metabolically, instead relying on prey sources for this HUFA (Webster \& Lovell 1990, Lemm \& Lemarie 1991, Tuncer \& Harrell 1992)

Lipid concentration of prey did not affect initial gas bladder inflation in Theragra chalcogramma larvae, agreeing with results reported for larvae of other species, e.g. gilthead seabream Sparus aurata (Koven 
et al. 1990) and Morone saxatilis (Lemm \& Lemarie 1991). However, T. chalcogramma larvae reared on a lipid-deficient diet had reduced growth, smaller gas bladders and higher mortality. While T. chalcogramma larvae are negatively buoyant and therefore need to actively swim to remain in the water column, larvae with smaller gas bladders required more active swimming to maintain position in the water column than did those with larger gas bladders. Larvae with smaller gas bladders also sank in a head down orientation which probably increased their sinking speeds, although we could not discern this for fresh killed larvae. The increase in energy expenditures associated with longer bouts of swimming could conceivably contribute to decreased growth and increased mortality. Hypertrophy and loss of function of the gas bladder of Dicentrarchus labrax was associated with feeding on lipid deficient Artemia salina (Katavic 1986). Gas bladder hypertrophy caused $D$. labrax larvae to float near the surface, interfering with swimming and feeding ability and leading to death.

Variable growth rates of Theragra chalcogramma larvae have been found in the Gulf of Alaska (Kendall et al. 1987, Yoklavich \& Bailey 1990) and this variability may be associated with variability in food type or availability (Kendall et al. 1987, Grover 1990). In addition, our study suggests that variable HUFA content of prey may be associated with alteration of buoyancy control, ability to vertically migrate, and survival of $T$. chalcogramma larvae. It remains to be tested that growth and survival of $T$. chalcogramma larvae in the sea may be at times controlled by nutrient content of prey.

Acknowledgements. We thank Michael Burger for technical assistance with rearing fish larvae; Sam Beattie and Dr Rosemary Wander for lipid analysis; and Art Kendall, Gail Theilacker, Kevin Bailey and Jeff Napp for helpful review of an early draft of the manuscript. This work is a contribution to NOAA's Fisheries-Oceanography Coordinated Investigations, FOCI-0175.

\section{LITERATURE CITED}

Alexander, R. McN. (1972). The energetics of vertical migration by fishes. Symp. Soc. exp. Biol. 26: 273-294

Attwood, C. G., Peterson, W. T. (1989). Reduction in fecundity and lipids of the copepod Calanus australis (Brodskii) by strongly pulsed upwelling. J. exp. mar. Biol. Ecol. 129: $121-131$

Bailey, K. M., Stehr, C. L. (1986). Laboratory studies on the early life history of the walleye pollock, Theragra chalcogramma (Pallas). J. exp. mar. Biol. Ecol. 99: 233-246

Battaglene, S. C. Talbot, R. B. (1990). Initial swim bladder inflation in intensively reared Australian bass larvae, Macquaria novemaculeata (Steindachner) (Perciformes: Percichthyidae). Aquaculture 86: 431-442
Bell, M. V., Henderson R. J., Sargent, J. R. (1986). The role of polyunsaturated fatty acids in fish. Comp. Biochem. Physiol. 83B: 711-719

Blaxter, J. H. S., Ehrlich, K. F. (1974). Changes in behavior during starvation of herring and plaice larvae. In: Blaxter, J. H. S. (ed.) The early life history of fish. Springer-Verlag, Berlin, p. 575-588

Blaxter, J. H. S., Tytler, P. (1978). Physiology and function of the swimbladder. Adv. comp. Physiol. Biochem. 7: 311-367

Bligh, E. G., Dyer, W. J. (1959). A rapid method of total lipid extraction and purification. Can. J. Biochem. Phys. 37: $911-917$

Borchers, P., Hutchings, L. (1986). Starvation tolerance, development time and egg production of Calanoides carinatus in the Southern Benguela Current. J. Plankton Res. 8: $855-874$

Dabrowski, K., Rusiecki, M. (1983). Content of total and free amino acids in zooplanktonic food of fish larvae. Aquaculture 30: 31-42

Dagg, M. (1977). Some effects of patchy food environments on copepods. Limnol. Oceanogr. 22: 99-107

Dendrinos, P., Thorpe, J. P. (1987). Experiments on the artificial regulation of the amino acid contents of food organisms to meet the assessed nutritional requirements of larval, post-larval and juvenile Dover sole (Solea solea L.). Aquaculture 61: 121-154

Doroshev, S. I., Cornacchia, J W., Hogan, K. (1981). Initial swim bladder inflation in the larvae of physoclistous fishes and its importance for larval culture. Rapp. P.-v. Réun. Cons. int. Explor. Mer 178: 495-500

Food \& Agriculture Organization (1988). Yearbook of fishery statistics, Vol. 62. FAO, Rome

Fraser, A. J., Gamble, J. C., Sargent, J. R. (1988). Changes in lipid content, lipid class composition and fatty acid composition of developing eggs and unfed larvae of cod (Gadus morhua). Mar. Biol. 99: 307-313

Fraser, A. J., Sargent, J. R., Gamble, J. C. (1989). Lipid class and fatty acid composition of Calanus finmarchicus (Gunnerus), Pseudocalanus sp. and Temora longicornis Muller from a nutrient-enriched seawater enclosure. J. exp. mar. Biol. Ecol. 130: 81-92

Fyhn, H. J. (1989). First feeding of marine fish larvae: are free amino acids the source of energy? Aquaculture 80: $111-120$

Fyhn, H. J., Serigstad, B. (1987). Free amino acids as energy substrates in developing eggs and larvae of the cod Gadus morhua. Mar. Biol. 96: 335-341

Grover, J. (1990). Feeding ecology of late-larval and earlyjuvenile walleye pollock Theragra chalcogramma from the Gulf of Alaska in 1987. Fish. Bull. U.S. 88: 463-470

Hakanson, J. L. (1984). The long and short term feeding condition in field-caught Calanus pacificus, as determined from the lipid content. Limnol. Oceanogr. 29: 794-804

Hakanson, J. L. (1989). Condition of larval anchovy (Engraulis mordax) in the Southern California Bight, as measured through lipid analysis. Mar. Biol. 102: 153-159

Haury, L. R., McGowan, J. A., Wiebe, P. H. (1978). Patterns and processes in the time-space scales of plankton distributions. In: Steele, J. H. (ed.) Spatial pattern in plankton communities. NATO Conference Series IV, Marine Science, 3. Plenum Press, New York, p. 277-327

Hunter, J. R. (1972). Swimming and feeding behavior of larval anchovy, Engraulis mordax. Fish. Bull. U.S. 70: 821-838

Hunter, J. R. (1981). Feeding ecology and predation of marine fish larvae. In: Lasker, R. (ed.) Marine fish larvae: morphology, ecology, and relation to fisheries. Washington Sea Grant Program, Univ. of Washington, Seattle, p. 33-77 
Katavic, I. (1986). Diet involvement in mass mortality of sea bass (Dicentrarchus labrax) larvae. Aquaculture 58 : $45-54$

Kendall, A. W. Jr, Clarke, M. E., Yoklavich, M. M., Boehlert, G. W. (1987). Distribution, feeding, and growth of larval walleye pollock, Theragra chalcogramma, from Shelikof Strait, Gulf of Alaska. Fish. Bull. U.S. 85: 499-521

Kitajima, C., Tsukashima, Y., Fujita, S., Watanabe, T., Yone, Y (1981). Relationship between uninflated swimbladders and lordotic deformity in hatchery reared red sea bream (Pagrus major). Bull. Jap. Soc. scient. Fish. 47: 1289-1294

Klungsøyr, J., Tilseth, S., Wilhelmsen, S., Falk-Petersen, S., Sargent, J. R. (1989). Fatty acid composition as an indicator of food intake in cod larvae Gadus morhua from Lofoten, Northern Norway. Mar. Biol. 102: 183-188

Koven, W. M., Tandler, A., Kissil, G. Wm., Sklan, D., Friezlander, O., Harel, M. (1990). The effect of dietary $(n-3)$ polyunsaturated fatty acids on growth, survival and swim bladder development in Sparus aurata larvae. Aquaculture 91: 131-141

Lasker, R. (1975). Field criteria for survival of anchovy larvae: the relation between inshore chlorophyll maximum layers and successful first feeding. Fish. Bull. U.S. 73: 453-462

Lasker, R. (1981). The role of a stable ocean in larval fish survival and subsequent recruitment. In: Lasker, R. (ed.) Marine fish larvae: morphology, ecology, and relation to fisheries. Washington Sea Grant Program, Univ. of Washington, Seattle, p. 79-87

Lee, R. F., Hirota, J., Barnett, A. M. (1971). Distribution and importance of wax esters in marine copepods and other zooplankton. Deep Sea Res. 18: 1147-1165

Leger, P., Bengtson, D. A., Simpson, K. L., Sorgeloos, P. (1986). The use and nutritional value of Artemia as a food source. Oceanogr. mar. Biol. A. Rev. 24: 521-623

Lemm, C. A., Lemarie, D. P. (1991). Survival and growth of larval striped bass (Morone saxatilis) fed Artemia enriched with highly unsaturated fatty acids (HUFA). Aquaculture 99: $117-126$

Mullin, M. M., Brooks, E. R. (1976). Some consequences of the distributional heterogeneity of phytoplankton and zooplankton. Limnol. Oceanogr. 21: 784-796

Napolitano. G. E., Ackman, R. G., Ratnayake, W. M. N. (1990). Fatty acid composition of three cultured algal species (Isochrysis galbana, Chaetoceros gracilis and Chaetoceros

This article was presented by R. S. Batty, Oban, Scotland calcitrans) used as food for bivalve larvae. J. Wld Aquacult. Soc. 21: 122-130

Olla, B. L., Davis, M. W. (1990). Effects of physical factors on the vertical distribution of larval walleye pollock Theragra chalcogramma under controlled laboratory conditions. Mar. Ecol. Prog. Ser. 63: 105-112

Opstad, I., Strand, B., Huse, I., Garatun-Tjeldsto, O. (1989). Laboratory studies on the use of rotifers (Brachionus plicatilis O.F. Müller) as start-feed for cod larvae (Gadus morhua L.). Aquaculture 79: 345-351

Pedersen, B. H., Hjelmeland, K. (1988). Fate of trypsin and assimilation efficiency in larval herring (Clupea harengus) following digestion of copepods. Mar. Biol. 97: 467-476

Radin, N. S. (1981), Extraction of tissue lipids with a solvent of low toxicity. In: Lowenstein, J. M. (ed.) Methods in enzymology 72(D). Academic Press, New York, p. 5-7

Rajendran, N., Fujiyoshi, E., Matsuda, O. (1991). Fatty acids and fatty alcohols of zooplankton from coastal upwelling area of Hyuga Nada, Japan. Nippon Suisan Gakkaishi 57 : $2277-2284$

Schwarz, A. (1971). Swimbladder development and function in the haddock, Melanogrammus aeglefinus L. Biol. Bull. 141: 176-188

Song, J., Wander, R. C. (1991). Effects of dietary selenium and fish oil (MaxEPA) on arachidonic acid metabolism and hemostatic function in rats. J. Nutr 121: 284-292

Tuncer, H., Harrell, R. M. (1992). Essential fatty acid nutrition of larval striped bass (Morone saxatilis) and palmetto bass (M. saxatilis $\times$ M. chrysops). Aquaculture 101: 105-121

Watanabe, T (1982). Lipid nutrition in fish. Comp. Biochem Physiol. 73B: 3-15

Watanabe, I., Kitajima, C., Fujita, S. (1983). Nutritional values of live organisms used in Japan for mass propagation of fish: a review. Aquaculture 34: 115-143

Webster, C. D., Lovell, R. T. (1990). Response of striped bass larvae fed brine shrimp from different sources containing different fatty acid compositions. Aquaculture 90: 49-61

Willason, S. W., Favuzzi, J., Cox, J. L. (1986). Patchiness and nutritional condition of zooplankton in the California current. Fish. Bull. U.S. 84: 157-176

Yoklavich, M. M., Bailey, K. M. (1990). Hatching period, growth and survival of young walleye pollock Theragra chalcogramma as determined from otolith analysis. Mar. Ecol. Prog. Ser. 64: 13-23

Manuscript first received: April 1, 1992

Revised version accepted: November 6, 1992 